\title{
Radiolabeling and Preclinical Evaluation of a New S-Alkylated Cysteine Derivative Conjugated to C-Substituted Macrocycle for Positron Emission Tomography
}

\author{
Surbhi Prakash, Puja Panwar Hazari,* Virendra Kumar Meena, and Anil Kumar Mishra*๑ \\ Division of Cyclotron and Radiopharmaceutical Sciences, Institute of Nuclear Medicine and Allied Sciences, Brig. S. K. Mazumdar \\ Road, Delhi 110054, India
}

Supporting Information

\begin{abstract}
A new S-alkylated cysteine-derivatized tumor targeting agent, 2,2'-(12-(2-((2-acetamido-2-carboxyethyl)thio)acetamido)-11,13-dioxo-1,4,7,10-tetraazacyclotridecane-4,7-diyl)diacetic acid was developed for positron emission tomography (PET) imaging. N-Acetyl cysteine (NAC) was conjugated to ATRIDAT as a specific targeting agent toward L-type and ASC amino acid transporter systems in the oncogenic cells. NAC was attached via $S$-alkylation to prevent its incorporation at undesired recognition sites affecting the signal-to-noise ratio. NACATRIDAT was subjected to gallium-68 complexation with $>75 \%$ radiolabeling yield. The radiocomplex was purified through the tc18 cartridge to obtain $99.89 \%$ radiochemical yield. IC-50 of the NAC-ATRIDAT conjugate was $0.8 \mathrm{mM}$ in A549 cells as evaluated through 3-(4,5-dimethylthiazol-2-yl)-2,5-diphenyltetrazonium bromide assay. Binding affinity experiments on A549 cells showed noteworthy binding with $K_{\mathrm{D}}$ in the nanomolar range. A time course study showed a $K_{\mathrm{m}}$ value of $0.19 \mu \mathrm{M}$ and $V_{\max }$ value of $0.49 \mathrm{pmol} / \mu \mathrm{g}$ protein/min showing reasonable tumor kinetics. Efflux studies showed that the synthesized radioligand is transported majorly by LAT followed by the ASC system. Clearance was found to be renal with $7.67 \pm 1.48 \%$ ID/ g uptake at $30 \mathrm{~min}$ which substantially declined to $0.52 \pm 0 . \% \mathrm{ID} / \mathrm{g}$ at $4 \mathrm{~h}$. A significant uptake of $10.06 \pm 1.056 \% \mathrm{ID} / \mathrm{g}$ was observed at the tumor site in mice at $1 \mathrm{~h} . \mu \mathrm{PET}$ images revealed a high contrast with a tumor-to-kidney ratio of 4.8 and a tumorto-liver ratio of 35.85 at $1 \mathrm{~h}$ after injection. These preclinical in vitro and in vivo evaluation supports its potential on the way of becoming a successful ${ }^{68} \mathrm{Ga}$-radiolabeled amino acid-based PET imaging agent.
\end{abstract}

\section{INTRODUCTION}

Amino acids and their derivatives labeled with radioactive isotopes are being extensively used in clinics and research labs as positron emission tomography (PET)/single-photon emission computed tomography imaging agents. Enhanced accretion of amino acids in tumor cells as a consequence of increased amino acid transport and protein synthesis is primarily responsible for their role in cancer imaging. ${ }^{1-5}$ The increase in the number of amino acid transporters in oncogenic proliferating cells has been documented by scientists in their reports. Among the transporters, the L-type transport system is markedly elevated in the cancer cells and is a key factor for transport of amino acids in them. ${ }^{6-9}$ Also, the finding that imaging with amino acids is less influenced by the inflammatory changes in the body makes it a lucrative system for diagnostic imaging. ${ }^{2}$

Many ${ }^{18}$ F-radiolabeled amino acids have been advanced for clinical PET applications. 4- $\left[{ }^{18} \mathrm{~F}\right]$ fluoro-L-phenylalanine $\left(\left[{ }^{18} \mathrm{~F}\right] \mathrm{FPhe}\right)$ and 2 - $\left[{ }^{18} \mathrm{~F}\right]$ fluoro-L-tyrosine $\left(\left[{ }^{18} \mathrm{~F}\right] \mathrm{FET}\right)$ have shown promising results, yet their complicated radiolabeling procedures and low radiochemical yields are a limitation. ${ }^{10-13}$ $\mathrm{O}$-(2-[ $\left[{ }^{18} \mathrm{~F}\right]$-fluoroethyl)-L-tyrosine ([ $\left.\left[{ }^{18} \mathrm{~F}\right] \mathrm{FET}\right), 2-\left[{ }^{18} \mathrm{~F}\right]$ fluoro-
$R$-methyl-L-tyrosine ([$\left.\left[{ }^{18} \mathrm{~F}\right] \mathrm{FMT}\right)$, and $\left[{ }^{18} \mathrm{~F}\right] \mathrm{FDOPA}$ are other ${ }^{18}$ F-labeled PET tracers, but their use focusses on brain-related abnormalities mainly. ${ }^{14-19}$ Outside the brain, their uptake is moderate in tumor tissues as compared to the surrounding healthy tissues, giving a poor to average target-to-nontarget ratio. Some recently synthesized compounds, 3-[ $\left.{ }^{18} \mathrm{~F}\right]$ fluoro-2methyl-2-(methylamino)propanoic acid ([ $\left.\left.{ }^{18} \mathrm{~F}\right] \mathrm{NMeFAMP}\right), 2$ amino-3- $\left[{ }^{18} \mathrm{~F}\right]$ fluoro-2-methylpropanoic acid ([$\left.\left.{ }^{18} \mathrm{~F}\right] \mathrm{FAMP}\right), 1$ amino-3- $\left[{ }^{18} \mathrm{~F}\right]$ fluorocyclobutyl-1-carboxylic acid $\left(\left[{ }^{18} \mathrm{~F}\right]\right.$ FACBC), and 1-amino-3- $\left[{ }^{18} \mathrm{~F}\right]$ fluoromethyl-cyclobutane-1-carboxylic acid ( $\left.\left[{ }^{18} \mathrm{~F}\right] \mathrm{FMACBC}\right)$ have shown good localization at the brain and tumor site. ${ }^{20-23}$

$S-{ }^{11} \mathrm{C}$-methyl-L-methionine $\left({ }^{11} \mathrm{C}-\mathrm{MET}\right)$ is an extensively used PET tumor imaging agent based on an amino acid. However, owing to its incorporation in the protein segments via the amino-acyl-transfer RNA pathway along with its degradation products, ${ }^{11} \mathrm{C}$-MET produces a significant amount

Received: January 10, 2018

Accepted: June 5, 2018

Published: June 18, 2018 
Scheme 1. Synthesis of 2,2'-(12-(2-((2-Acetamido-2-carboxyethyl)thio)acetamido)-11,13-dioxo-1,4,7,10tetraazacyclotridecane-4,7-diyl)diacetic Acid $^{a}$

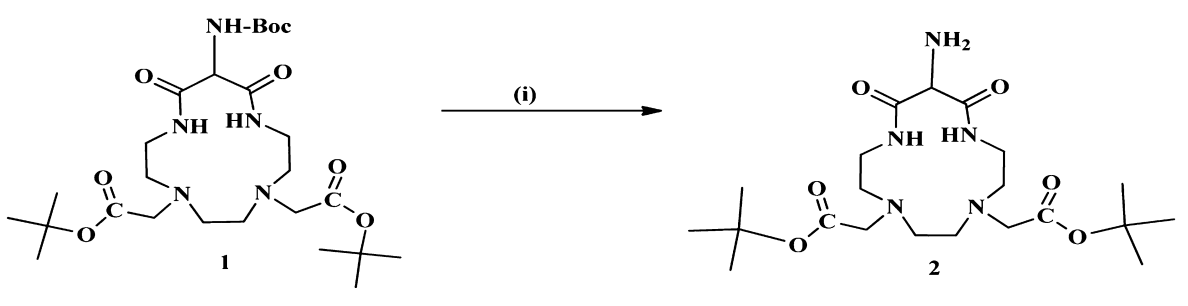

(ii)

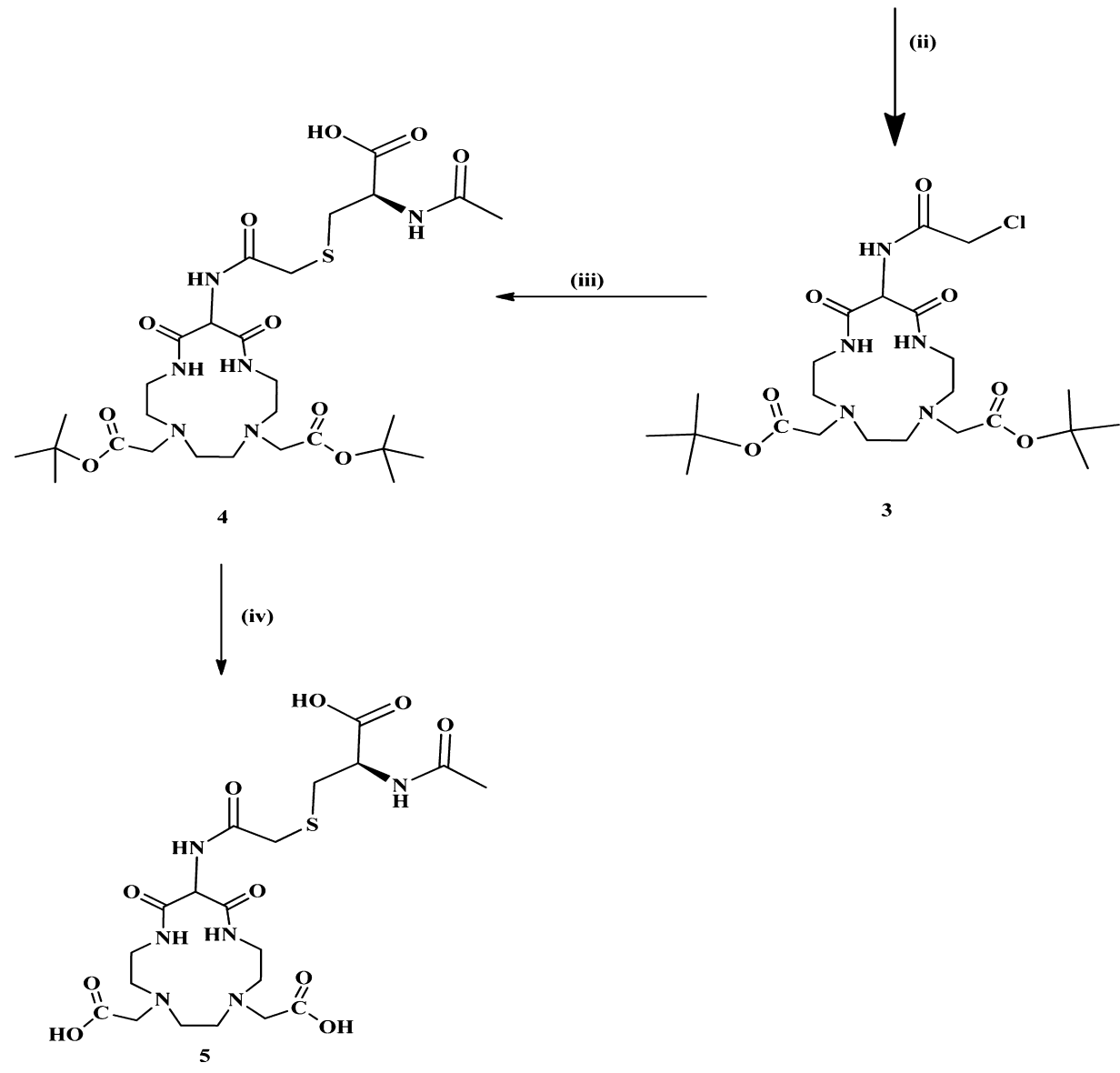

${ }^{a}$ Conditions:(i) EAA/ $\mathrm{HCl}$, r.t.; (ii) $\mathrm{ClCH}_{2} \mathrm{COCl}, \mathrm{K}_{2} \mathrm{CO}_{3}, \mathrm{CHCl}_{3} / \mathrm{H}_{2} \mathrm{O}, 0{ }^{\circ} \mathrm{C}$; (iii) $\mathrm{N}$-acetyl L-cysteine, $\mathrm{NaOMe}$, anhydrous $\mathrm{MeOH}$, r.t.; (iv) TFA, dichloromethane (DCM), $0{ }^{\circ} \mathrm{C}$.

of radioactive metabolites which leads to a decrease in its specificity and selectivity in vivo. ${ }^{24}$ Also, MET gets assimilated into nonprotein matter like phospholipids and RNA through the transmethylation process (transfer of its radiolabeled methyl group) via $S$-adenosyl-L-methionine. ${ }^{25}$ Both these side reactions create substantial nonspecific background signal, making quantitative imaging very difficult at the tumor target site.

All these amino acid derivatives have been radiolabeled with ${ }^{11} \mathrm{C}$ or ${ }^{18} \mathrm{~F}$, restricting their use in PET centers having an inhouse cyclotron facility or nearby cyclotron center. ${ }^{26-28}$ Bourdier et al. reported that an S-alkylated derivative can remove the chances of the amino acid analogue to participate in the side reactions and thus reduce the formation of secondary metabolites, resulting in the reduction of nonspecific signals/background noise. ${ }^{29}$ Deng et al. and Huang et al. also reported the synthesis of S-alkylated cysteine derivatives, with high uptake in the tumor and nearly no accumulation in the protein components. $^{26,27}$ Therefore an S-alkylated amino acid derivative PET imaging agent with a chelator, shown to possess high stability with metal ions in the $\mathrm{M}^{2+}$ and $\mathrm{M}^{3+}$ form, especially $\mathrm{Ga}(\mathrm{III})$, was proposed. ATRIDAT, already reported by our group to form thermodynamically stable and strong complexes with $\mathrm{Ga}$ (III) was used for conjugating the cysteine derivative after slight modification in the pendant arm, keeping the macrocyclic framework intact. ${ }^{30}$ PET is a highly sensitive technique which provides a method to visualize and quantify the uptake at the target site. PET aids in early diagnosis, as it detects the changes in the biochemical pathways, allowing detection of disease before the appearance of anatomical changes. Being a generator-produced radioisotope along with an ideal half-life, ${ }^{68} \mathrm{Ga}$ with its optimum isotope energy makes an attractive radioisotope for PET imaging. The comparatively shorter half-life of ${ }^{68} \mathrm{Ga}$ and hydrophilic nature of the complex allows rapid renal clearance which ultimately reduces the radiation burden to the patient. ${ }^{68} \mathrm{Ga}$-PET is extensively used 
in the diagnosis and management of tumors owing to defined chemistry of $\mathrm{Ga}(\mathrm{III})$ with triaza- and tetraaza macrocyclic molecules. $^{31,32}$

\section{RESULTS AND DISCUSSION}

Synthesis. Synthetic strategy utilizes S-alkylation of $\mathrm{N}$ acetyl cysteine (NAC) with a chloroacetylated derivative of a 13-membered protected macrocycle, di-tert-butyl 2,2'-(12((tert-botoxycarbonyl)amino)-11,13-dioxo-1,4,7,10-tetraazatridecane-4,7-diyl)diacetate $(\mathbf{1})^{30}$ (Scheme 1). The Boc group of this macrocycle (1) was selectively cleaved using $\mathrm{HCl}$ gas dissolved in ethyl acetate, exposing the amine group for further reaction to give compound 2 . This reaction occurs in 2-3 h, and the product formed precipitates as a pale yellow solid in the reaction solvent which can be used as such without further purification. The free amine group was then chloroacetylated (3) to alkylate NAC (bio vector) from the thiol side to synthesize compound 4. Conjugation of the biovector was confirmed by the presence of an additional peak for 3 protons at $2 \mathrm{ppm}$ (for methyl protons of the acetyl group) in the ${ }^{1} \mathrm{H}$ NMR spectra and the peak at $23 \mathrm{ppm}$ for the carbon of this methyl group in the ${ }^{13} \mathrm{C}$ spectra. A peak at $176 \mathrm{ppm}$ appears in the ${ }^{13} \mathrm{C}$ spectra, for the carboxyl group of the cysteine. In mass spectra, the conjugation is confirmed by the $[\mathrm{M}+\mathrm{H}]^{+}$peak at $661.5 \mathrm{~m} / z$. This intermediate on trifluoroacetic acid (TFA) treatment gave the final compound (5) confirmed by the $[\mathrm{M}-$ $\mathrm{H}]^{-}$peak at $m / z 547.3$ in the mass spectra. All synthesized compounds were characterized through spectroscopic techniques such as NMR and mass spectrometry (see the Supporting Information). The synthesized molecule targets the enhanced amino acid uptake and the elevated AA transporters in the tumor cells and S-alkylated to prevent its incorporation in the nondesired protein/nonprotein segments for high tumor-tobackground ratio.

Radiolabeling, Serum Stability and log P. The labeling of ATRIDAT-NAC was performed with ${ }^{68} \mathrm{Ga}$ using middle fraction of the ${ }^{68} \mathrm{Ge} /{ }^{68} \mathrm{Ga}$ generator elute. ${ }^{68} \mathrm{Ga}$-radiolabeling of ATRIDAT-NAC was accomplished at the ambient temperature of $90{ }^{\circ} \mathrm{C}$ for $10 \mathrm{~min}$ at $\mathrm{pH} 4.5$. Temperature less than 90 ${ }^{\circ} \mathrm{C}$ or reduced time of heating significantly decreased the radiolabeling yield. A decent radiochemical yield of $78 \%$ with 98.9\% radiochemical purity and $5 \mathrm{MBq} / \mathrm{nmol}$ of specific activity was obtained after $\mathrm{C}-18$ cartridge purification. The radiocomplex was confirmed through EZ-thin-layer chromatography (TLC), with the dominant peak showing the ${ }^{68} \mathrm{Ga}$ ATRIDAT-NAC moiety. The radiolabeled compound exhibited more than $97 \%$ stability in human serum upto $60 \mathrm{~min}$ which reduced to $75 \%$ after $4 \mathrm{~h}$ incubation when traced with instant TLC (ITLC) (see the Supporting Information for the HPLC profile, EZ-TLC, radiolabeling optimization and serum stability graphs). The intact percentage of the radiotracer is reasonable to perform the biological studies with 3-4 h duration. The distribution of the radiotracer in octanol and phosphate buffered saline (PBS) gave a log P value of $-2.63 \pm$ 0.04 showing its greater affinity toward the hydrophilic system.

Cell Viability Assay. The in vitro cytotoxicity of the conjugate was assessed by incubating A549 cells with different concentrations of ATRIDAT-NAC at 24, 48, and $72 \mathrm{~h}$ time intervals. At lower concentrations of the ligand, no significant toxicity was observed. At $1 \mathrm{mM}$ concentration of the compound, $70.76 \pm 1.64 \%$ viability was obtained at $24 \mathrm{~h}$ which decreased to $67.52 \pm 0.54 \%$ at $48 \mathrm{~h}$ and $56.37 \pm 1.73 \%$ at $72 \mathrm{~h}$ of incubation (Figure 1). $\mathrm{IC}_{50}$ in A549 cells was observed to be $0.8 \mathrm{mM}$, indicating its safe and nontoxic behavior. Toxicity of cells was observed to be dose-dependent at all time points.

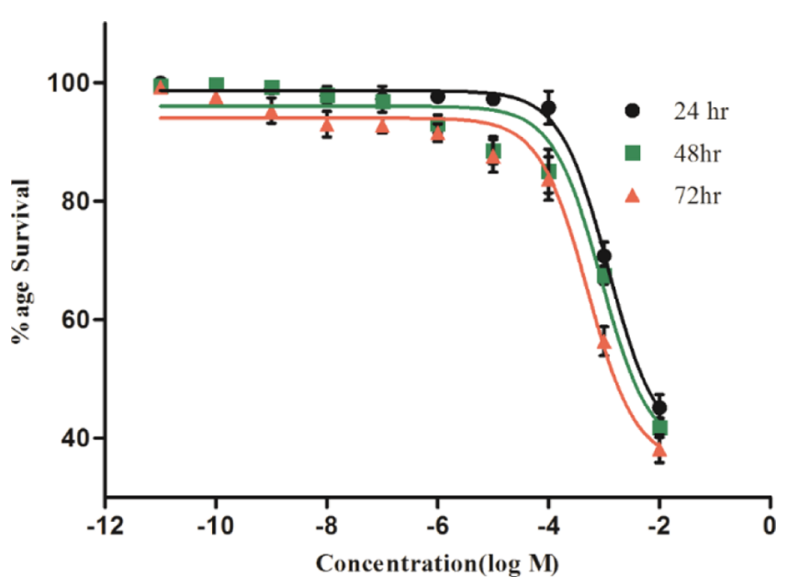

Figure 1. Cytotoxicity assay curve of ATRIDAT-NAC in A549 cells performed for 24,48 , and $72 \mathrm{~h}$ duration from $1 \mathrm{pM}$ to $10 \mathrm{mM}$ concentration range.

Time Course and Kinetics Study. Time progression analysis showed that the transport of ${ }^{68}$ Ga-ATRIDAT-NAC into A549 cells was fast and linear upto $30 \mathrm{~min}$, then reaching saturation at $60 \mathrm{~min}$ of incubation. Linear correlation was seen as a result of a saturable system because of $L$ followed by the ASC transporter system in Eadie-Hofstee transformation (Figure 2). A kinetic study revealed a Michaelis constant $\left(K_{\mathrm{m}}\right)$ value of $0.19 \mu \mathrm{M}$ and $V_{\max }$ (maximal transport rate) with a value of $0.49 \mathrm{pmol} / \mu \mathrm{g}$ protein $/ \mathrm{min}$.

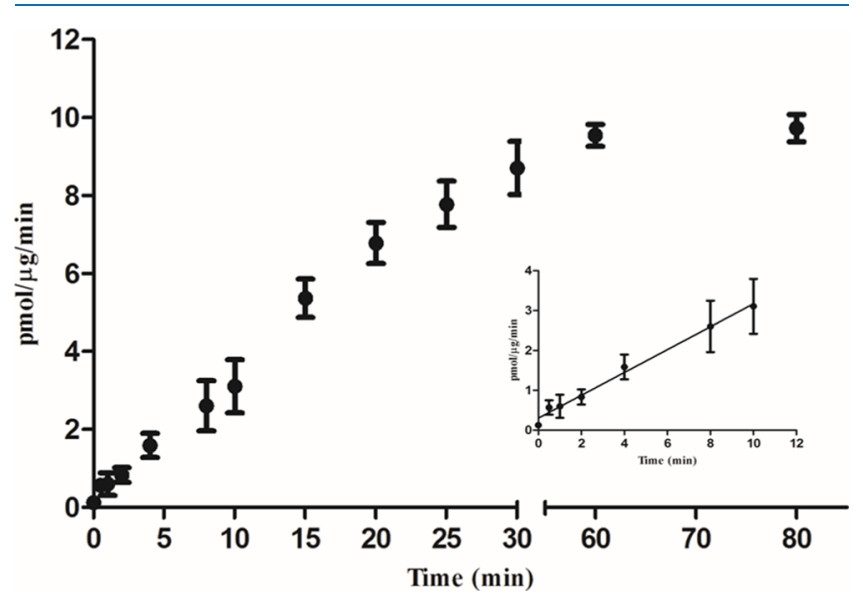

Figure 2. Time course of ${ }^{68} \mathrm{Ga}$-ATRIDAT-NAC. Uptake was seen from 0.5 to $60 \mathrm{~min}$. The inset depicts an Eadie-Hofstee graph of saturable transport. The experiment was performed in triplicates, and values are mean $\mathrm{SD}$ of 3 measurements.

Cell Binding Studies. Cell binding assay of ${ }^{68} \mathrm{Ga}$ ATRIDAT-NAC was done on A549 cells to assess the binding of the radioconjugate to the transporters on the surface of tumor cells. Nonspecific binding was evaluated by the addition of 100 times excess of unlabeled cold NAC. The binding curve revealed appreciable binding of ATRIDAT-NAC on the A549 tumor cell line surface (Figure 3). The Scatchard plot analysis showed significant affinity of the synthesized compound on the 
tumor cells. The dissociation constant $\left(K_{\mathrm{D}}\right)$ was observed to be $5.5 \mathrm{nM}$

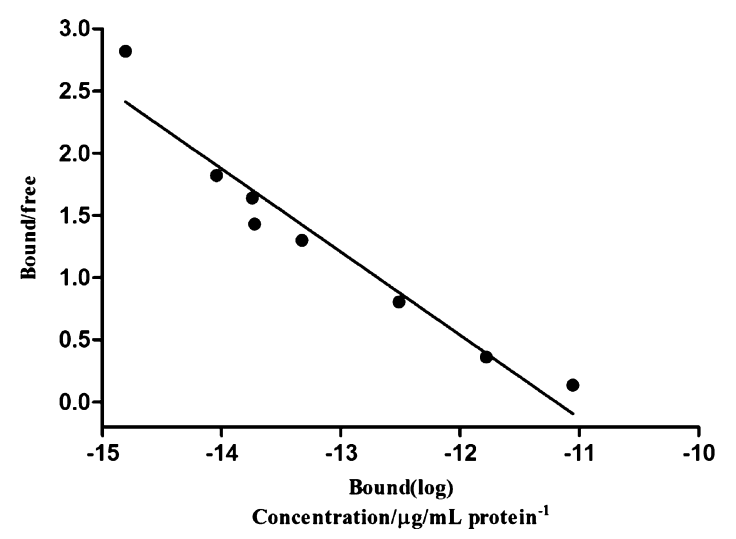

Figure 3. Displacement of ${ }^{68} \mathrm{Ga}$-ATRIDAT-NAC using excess unlabeled cold NAC. Scatchard plot showing the specific binding of the radiolabeled compound to the ratio of bound to free for A549 cells.

$\mathrm{Na}^{+}$-Dependent/-Independent Efflux Study. Amino acid efflux studies were conducted with and without the presence of $\mathrm{Na}^{+}$to assess the specificity of ${ }^{68} \mathrm{Ga}$-ATRIDATNAC for its transporter associated with uptake by A549 cells. This experiment was performed with the control set where no amino acid was added in the buffer solutions. It is worthwhile to note that the transport kinetics was similar to that of cysteine. The addition of $\mathrm{Na}^{+}$has shown a pattern of efflux in the presence of other amino acids including alanine, DOPA, phenyl alanine, and glutamine. The replacement of $\mathrm{Na}^{+}$by choline showed slightly decreased the uptake of ${ }^{68} \mathrm{Ga}$ ATRIDAT-NAC in cysteine-containing buffer solution. There was $90 \%$ efflux of ${ }^{68} \mathrm{Ga}$-ATRIDAT-NAC as compared to control in the case of $\mathrm{Na}^{+}$and cysteine-containing solution, whereas $83 \%$ efflux in the case of $\mathrm{Na}^{+}$-independent conditions (Figure 4). The results suggested that ${ }^{68} \mathrm{Ga}$-ATRIDAT-NAC is primarily transported and mediated mainly by $\mathrm{L}$ type with minor transport system ASC.

Incorporation of ${ }^{68} \mathrm{Ga}-\mathrm{ATRIDAT}-\mathrm{NAC}$ into Proteins. This experiment was done to check the influence of $S$ alkylation on the amino acid-based radioligand incorporation in the protein segments. Less than $2 \%$ radioactivity was found

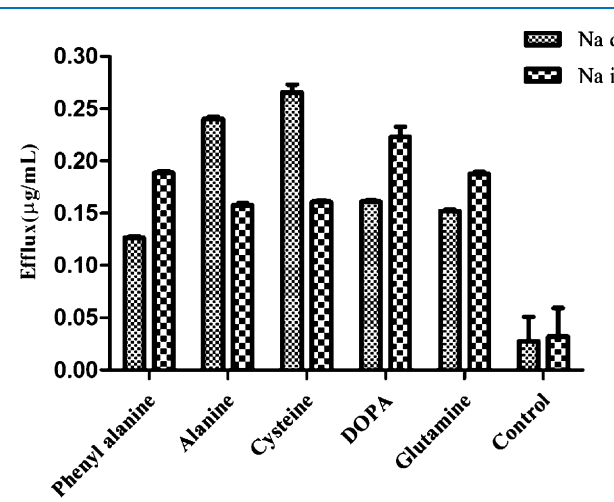

Figure 4. Efflux study of ${ }^{68}$ Ga-ATRIDAT-NAC by different amino acids in sodium-containing and sodium-absent media in A549 cells at $t=60 \mathrm{~min}$ at $25^{\circ} \mathrm{C}$. The experiment was performed in duplicates in 3 sets with control, $n=3$, values are mean \pm SD. in samples precipitated with trichloroacetic acid (TCA) in the acid insoluble fraction after 30 min incubation with ${ }^{68} \mathrm{Ga}$ ATRIDAT-NAC. Almost all the activity was retained in the acidic fraction. Incorporation of ${ }^{68} \mathrm{Ga}$-ATRIDAT-NAC into protein was not observed.

Blood Kinetics, $\mu$ PET Imaging, and Biodistribution. The blood clearance study was performed in rats till $4 \mathrm{~h}$. It showed rapid clearance of the radioligand, ${ }^{68} \mathrm{Ga}$-ATRIDATNAC from blood with $31.99 \%$ remaining after $30 \mathrm{~min}$. After 30 min, the compound showed gradual clearance from the blood with $19.8 \%$ remaining at $2 \mathrm{~h}$ and $16.3 \%$ remaining at $4 \mathrm{~h}$ (see the Supporting Information, Figure S13).

$\mu$ PET scanning was carried out to evaluate the potential of ${ }^{68}$ Ga-ATRIDAT-NAC to target A549 tumor cells xenograft in the forelimb of athymic mice for diagnostic applications. An increased uptake of the radiotracer at the tumor site was seen which improved with time as compared to other organs. In vivo $\mu$ PET scans of A549 xenograft in nude mice showed high localization of ${ }^{68} \mathrm{Ga}$-ATRIDAT-NAC at the desired site, while there was minimal activity accumulation in the blood pool organs (Figure 5). A slight uptake at the kidney and liver sites

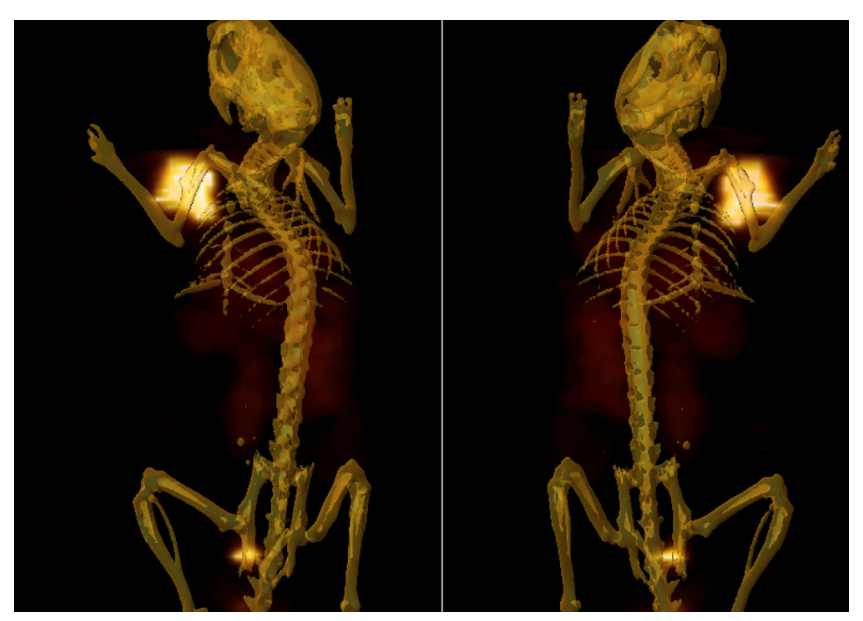

Figure 5. $\mu \mathrm{PET} /$ computed tomography (CT) scintigraphic scan of ${ }^{68} \mathrm{Ga}$-ATRIDAT-NAC injected in nude mice with A549 tumor cells xenograft in the forelimb at $1 \mathrm{~h}$ after injection. 3D-rendered reconstructed $\mu \mathrm{PET} / \mathrm{CT}$ image using AMIRA 4.1.1.

was seen at $1 \mathrm{~h}$ which decreased further when seen in the $2 \mathrm{~h}$ delayed images. Low retention in liver and kidneys was observed because of the hydrophilic nature of the radioconjugate. The regions of interest (ROIs) as calculated semiquantitatively have shown $95.23 \mathrm{kBq} / \mathrm{mm}^{3}$ of the dose in tumor, whereas in the kidney and liver, the doses were found to be 19.72 and $2.66 \mathrm{kBq} / \mathrm{mm}^{3}$ respectively (Table 1 ). The tumor-to-kidney ratio of 4.8 and tumor-to-liver ratio of 35.85 were achieved.

Biodistribution studies were carried out at different time intervals, namely, $0.5,1,2$, and $4 \mathrm{~h}$. The path of excretion was observed to be kidneys with $7.67 \pm 1.48 \%$ ID/g accumulation

Table 1. Table Representing ROIs of Different Organs

$\begin{array}{lc}\text { organ } & \text { ROI’s }\left(\mathrm{kBq} / \mathrm{mm}^{3}\right) \\ \text { tumor } & 95.23 \\ \text { kidney } & 19.72 \\ \text { liver } & 2.66\end{array}$


at $30 \mathrm{~min}$ after which the radioactivity in the kidneys declined considerably at $1 \mathrm{~h}$ with $2.08 \pm 0.66$ and $0.52 \pm 0.08 \% \mathrm{ID} / \mathrm{g}$ retaining at $4 \mathrm{~h}$. The brain showed less than $0.1 \%$ at all time intervals. The uptake in the bone was also negligible at all time points with $0.19 \pm 0.07 \% \mathrm{ID} / \mathrm{g}$ at $30 \mathrm{~min}$, the highest uptake value. The radioconjugate showed accretion of $4.15 \pm 0.16 \%$ $\mathrm{ID} / \mathrm{g}$ at $0.5 \mathrm{~h}$ in the liver which decreased to $0.38 \pm 0.09$ and $0.16 \pm 0.04 \% \mathrm{ID} / \mathrm{g}$ at 1 and $4 \mathrm{~h}$, respectively. The $\log P$ value plays a pivotal role in deciding the fate of excretion and formation of cationic species.

The $\log P$ value of -2.89 was obtained for $\left[{ }^{68} \mathrm{Ga}\right.$-ATRIDATNAC] because of which it followed the renal route of excretion followed by excretion through the liver. The tumor/kidney and tumor/liver ratios at different time intervals are shown in Table 2. Less than $0.5 \%$ uptake was observed in the stomach. In

Table 2. Table Representing Tumor/Kidney (T/K) and Tumor/Liver $(\mathrm{T} / \mathrm{L})$ Ratios at Different Time Points

$\begin{array}{ccr}\text { time }(\min ) & \mathrm{T} / \mathrm{K} & \mathrm{T} / \mathrm{L} \\ 30 & 0.32 & 0.59 \\ 60 & 4.83 & 26.47 \\ 120 & 7.64 & 32.38 \\ 240 & 8.69 & 28.25\end{array}$

tumor, a considerable uptake of $2.47 \pm 0.16 \% \mathrm{ID} / \mathrm{g}$ at $30 \mathrm{~min}$ was seen and rapid accumulation with a value of $10.06 \pm$ $1.05 \% \mathrm{ID} / \mathrm{g}$ at $1 \mathrm{~h}$. Further, a decrease of activity was seen at 2 $\mathrm{h}$ with $6.80 \pm 0.57 \% \mathrm{ID} / \mathrm{g}$ value which reduced to $4.52 \pm$ $0.61 \% \mathrm{ID} / \mathrm{g}$ at $4 \mathrm{~h}$ (Figure 6 ). The biodistribution statistics

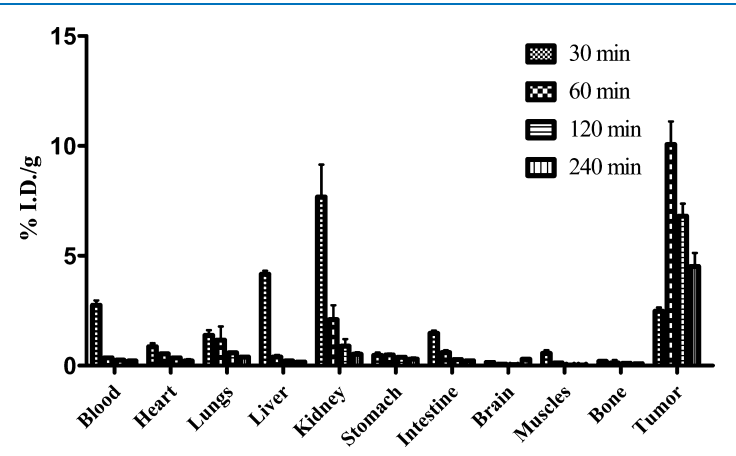

Figure 6. Biodistribution graph depicting accumulation of ${ }^{68} \mathrm{Ga}$ ATRIDAT-NAC following intravenous (i.v.) injection in nude mice xenografted with A549 tumor cells at different time intervals.

shows speedy clearance of the radiolabeled probe from the blood pool and other vital tissues. Apart from hydrophilic nature of the compound, the alkylated thiol group helps in reducing accumulation of activity in the background regions. This results in amplification of the signal at the tumor site.

\section{CONCLUSIONS}

A new S-alkylated radioligand, ${ }^{68}$ Ga-ATRIDAT-NAC, was synthesized, characterized, and preclinically assessed as a candidate agent for PET imaging. The synthesized compound was stable in human serum, possessing high binding affinity to A549 cells with $5.5 \mathrm{nM}$ of $K_{\mathrm{D}}$ and desirable tumor cell kinetics. Previous cysteine and methionine analogues with free thiol groups act as reactive species and get involved in different protein and nonprotein cycles. Herein, we alkylated the thiol group to avoid any side reactions to give high tumor to blood counts. A substantial accumulation of ${ }^{68} \mathrm{Ga}$-ATRIDAT-NAC at the tumor site validates its targeting efficiency at the desired site and therefore marks its potential as a PET diagnostic agent. ATRIDAT-NAC is very efficiently carried by the amino acid transport systems known to overexpress in the tumor cells. It was inferred that the uptake was mostly due to L-type with minor assistance from ASC transporters. A high uptake of radioactivity at the desired site, a pharmacokinetically stable radioligand with a simpler $\mathrm{Ga}-68$ radiopharmacy gives a great alternative to the already known C-11 and F-18 radiotracers.

\section{MATERIALS AND METHODS}

Chemicals and reagents consumed in the syntheses were obtained commercially and utilized without further purification unless notified.

Sodium methoxide in methanol, $N^{\prime}, N^{\prime}$-dimethyl formamide (anhydrous), $\mathrm{N}$-acetyl-L-cysteine, ethyl acetate, pet ether, chloroacetyl chloride, 1-octanol, sodium sulphate anhydrous, potassium carbonate, TFA, acetonitrile, methanol, DCM, chloroform, and water were purchased from E. Merck Ltd. (India). Among these, solvents were purchased of HPLC grade. Dulbecco's modified Eagle's medium (DMEM), penicillin, streptomycin sulphate, nystatin, and trypsin-ethylenediaminetetraacetic acid (EDTA) (10×) were bought from Sigma, USA. Foetal bovine serum was obtained from GIBCO.

The reactions demanding anhydrous conditions were carried under an inert $\mathrm{N}_{2}$ atmosphere. Anhydrous methanol was prepared by using $4 \AA$ molecular sieves. The reaction temperatures mentioned denote the temperature of the reaction vessel's water bath and not the reaction vessel itself. Aluminium-coated silica gel sheets (silica gel 60 F, Merck, Germany) were used to run TLC and seen by potassium permanganate developing solution. ITLC was done to assess radiocomplexation yield and percentage of radiochemical purity.

Instrumentation Details. The Bruker AVANCE II 400 $\mathrm{MHz}$ NMR system (ultra-shielded) was used for recording ${ }^{1} \mathrm{H}$ and ${ }^{13} \mathrm{C}$ NMR spectra. The Agilent 6310 system ion trap mass spectrometer was used for electrospray ionization mass spectroscopy (ESI-MS in positive and negative ion mode). High-resolution mass spectrometry-liquid chromatography mass spectrometry (HRMS-LCMS) coupled with the quadrupole time-of-flight mechanism was utilized to obtain accurate mass of the compounds at University of Delhi. The scintigraphic scan was taken using the GE FLEX Triumph LABPET4. $\mu$ PET module () having $2^{\prime} 2^{\prime} 10 \mathrm{~mm}^{3}$ LYSO/LGSO scintillators in an 8-pixel with avalanche photodiode detector module. Image analyses and reconstruction was accomplished using Amira 4.1.1 and AMIDE software. 3-(4,5-Dimethylthiazol-2-yl)-2,5-diphenyltetrazonium bromide (MTT) assay plates were recorded at $570 \mathrm{~nm}$ with a reference wavelength of $630 \mathrm{~nm}$ on a Synergy Hybrid H4 (BioTek Instruments, Winooski, VT, USA).

HPLC Details. The Agilent 1260 (infinity analytical scale purification) system was used to analyze the final compounds on the Atlantis T3 C18 reverse phase column $(5 \mu \mathrm{m}, 4.6 \mathrm{~mm}$ $\times 250 \mathrm{~mm}$ ). The mobile phase used was $0.05 \%$ TFA in water (solvent $\mathrm{A}, 60 \%$ ) and acetonitrile (solvent B, 40\%) in the isocratic mode with a flow rate of $0.8 \mathrm{~mL} / \mathrm{min}$ for $30 \mathrm{~min}$ and $10 \mu \mathrm{L}$ of injection volume. $R_{\mathrm{T}}$ (retention time) of $4.114 \mathrm{~min}$ was obtained for the final compound (see the Supporting Information). 
Cell Culture Details. DMEM supplemented media (10\% foetal bovine serum, $50 \mu \mathrm{g} / \mathrm{mL}$ streptomycin sulfate, $2 \mu \mathrm{g} / \mathrm{mL}$ nystatin, and $50 \mathrm{U} / \mathrm{mL}$ penicillin) was used to maintain the monolayer cultures of A549 cells. Cells were regularly cultured two times in a week using trypsin-EDTA (Sigma, USA) and kept at $37{ }^{\circ} \mathrm{C}$ in a $\mathrm{CO}_{2}$ incubator maintained at $5 \% \mathrm{CO}_{2}$ and 95\% air.

Animal Models. Animal procedures were permitted and executed according to the recommendations of INMAS's Animal Ethics Committee (reg. no. */GO/RBi/S/99/ CPCSEA). Animals were kept under sterile and controlled temperature of $22 \pm 2{ }^{\circ} \mathrm{C}$ and water and diet ad libitum. Xenografted athymic nude mice were used for scintigraphic and biodistribution studies. Cell suspension (100 $\mu \mathrm{L})$ of A549 cells containing $3 \times 10^{3}$ cells was inoculated subcutaneously in each mouse in the right forelimb. When the volume of tumor attained $>200 \mathrm{~mm}^{3}$, the A549 tumor xenografted mice were used for the in vivo studies. Wistar rat was used for blood kinetics.

Statistical Analysis. The Scatchard plot was analyzed through nonlinear retrogression using GraphPad Prism 5.0. Biodistribution data are represented as a graph depicting mean $\pm \mathrm{SD}$.

\section{EXPERIMENTAL SECTION}

Synthesis of Di-tert-butyl-2,2'-(12-amino-11,13dioxo-1,4,7,10-tetraazacyclotridecane-4,7-diyl)diacetate (2). To $5 \mathrm{~mL} 1 \mathrm{M}$ dry solution of $\mathrm{HCl}, 5 \mathrm{~mL}$ in ethyl acetate (containing $500 \mathrm{~mol} \%$ of $\mathrm{HCl}$ ), compound 1 (200 mg, $0.36 \mathrm{mmol}$ ) was added and stirred for $4-5 \mathrm{~h}$ in a round-bottom flask at room temperature. The product starts to precipitates out in ethyl acetate as the reaction progresses. Completion of reaction was checked through TLC for complete consumption of the reactant. Ethyl acetate was then decanted and the product dried in vacuo to yield a slightly yellowish compound 2 . The compound was subjected to the next step without any further purification. (123.22 mg, 0.27 mmol, 74.93\%): ${ }^{1} \mathrm{H}$ NMR (400 MHz, $25{ }^{\circ} \mathrm{C}, \mathrm{CDCl}_{3}$ ): 1.4 (s, $\left.18 \mathrm{H}, \mathrm{CH}_{3}\right), 2.4(\mathrm{br}, 2 \mathrm{H}, \mathrm{NH}), 2.6-2.7\left(\mathrm{~m}, 8 \mathrm{H}, \mathrm{CH}_{2}\right), 3.2-3.4$ $\left(\mathrm{m}, 8 \mathrm{H}, \mathrm{CH}_{2}\right), 4.1(\mathrm{~s}, 1 \mathrm{H}, \mathrm{CH}), 7.6(\mathrm{br}, 2 \mathrm{H}, \mathrm{NH}) .{ }^{13} \mathrm{C} \mathrm{NMR}$ $\left(100 \mathrm{MHz}, 25{ }^{\circ} \mathrm{C}, \mathrm{CDCl}_{3}\right): \delta(\mathrm{ppm}): 29.6,37.1,52.0,53.8$, 59.6, $81.8\left(4{ }^{\circ} \mathrm{C}\right), 169.6,171.2$; $\mathrm{ESI}^{-\mathrm{MS}^{+}: \mathrm{m} / z \text { calcd for }}$ $\mathrm{C}_{21} \mathrm{H}_{39} \mathrm{~N}_{5} \mathrm{O}_{6}[\mathrm{M}+\mathrm{H}]^{+}, 458.30$; found $[\mathrm{M}+\mathrm{H}]^{+}, 458.40$. HRMS (positive ions): $m / z$ calcd for $\mathrm{C}_{21} \mathrm{H}_{39} \mathrm{~N}_{5} \mathrm{O}_{6}[\mathrm{M}+\mathrm{H}]^{+}$, 458.2908; found $[\mathrm{M}+\mathrm{H}]^{+}, 458.2981$.

Synthesis of Di-tert-butyl2,2'-(12-(2-chloroacetamido)-11,13-dioxo-1,4,7,10-tetraazacyclotridecane-4,7diyl)diacetate (3). Compound $2(100 \mathrm{mg}, 0.22 \mathrm{mmol}$ ) was dissolved in $\mathrm{CHCl}_{3}(5 \mathrm{~mL})$ in a three-neck round-bottom flask maintained at ice-cold conditions. Potassium carbonate (90.59 $\mathrm{mg}, 0.66 \mathrm{mmol}$ ) was dissolved in $5 \mathrm{~mL} \mathrm{H}_{2} \mathrm{O}$, and the addition of chloroacetyl chloride $(20.5 \mu \mathrm{L}, 0.254 \mathrm{mmol})$ in $5 \mathrm{~mL}$ $\mathrm{CHCl}_{3}$ was done slowly over a period of $30 \mathrm{~min}$ using a dropping funnel. Ice conditions were maintained during the entire addition process, and then, the reaction was maintained at room temperature $\left(25^{\circ} \mathrm{C}\right)$ and allowed to stir overnight. The resultant solution was subjected to extraction using a separating funnel with $50 \mathrm{~mL}$ of $\mathrm{CHCl}_{3}$ thrice. The organic layer was removed and dried with anhydrous sodium sulphate and concentrated under reduced pressure. The concentrate was then triturated using pet ether to give 3 as a creamish compound. (92.39 mg, $0.173 \mathrm{mmol}, 78.65 \%):{ }^{1} \mathrm{H} \mathrm{NMR}(400$ $\left.\mathrm{MHz}, 25{ }^{\circ} \mathrm{C}, \mathrm{CDCl}_{3}\right): 1.4\left(\mathrm{~s}, 18 \mathrm{H}, \mathrm{CH}_{3}\right), 2.6-2.7(\mathrm{~m}, 8 \mathrm{H}$,
$\left.\mathrm{CH}_{2}\right), 3.1\left(\mathrm{~m}, 2 \mathrm{H}, \mathrm{CH}_{2}\right), 3.2\left(\mathrm{~m}, 4 \mathrm{H}, \mathrm{CH}_{2}\right), 4.1\left(\mathrm{~s}, 2 \mathrm{H}, \mathrm{CH}_{2}\right)$, 4.9 (s, $1 \mathrm{H}, \mathrm{CH}), 7.8(\mathrm{br}, 2 \mathrm{H}, \mathrm{NH}), 7.9(\mathrm{br}, 1 \mathrm{H}, \mathrm{NH}) .{ }^{13} \mathrm{C}$ NMR $\left(100 \mathrm{MHz}, 2{ }^{\circ} \mathrm{C}, \mathrm{CDCl}_{3}\right): \delta(\mathrm{ppm}): 29.6,37.5,42.3$, 52.4, 54.5, 58.0, $81.7\left(4{ }^{\circ} \mathrm{C}\right), 165.4,166.2,171.5$; ESI-MS ${ }^{+}: \mathrm{m} /$ $z$ calcd for $\mathrm{C}_{23} \mathrm{H}_{40} \mathrm{ClN}_{5} \mathrm{O}_{7}[\mathrm{M}+\mathrm{H}]^{+}, 534.27$; found $[\mathrm{M}+\mathrm{H}]^{+}$, 534.6. HRMS (positive ions): $\mathrm{m} / z$ calcd for $\mathrm{C}_{23} \mathrm{H}_{40} \mathrm{ClN}_{5} \mathrm{O}_{7}$ $[\mathrm{M}+\mathrm{H}]^{+}$, 534.2624; found $[\mathrm{M}+\mathrm{H}]^{+}, 534.2705$.

Synthesis of 2-Acetamido-3-((2-)(4,7-bis(2-(tert-butoxy)-2-oxoethyl)-11,13-dioxo-1,4,7,10-tetraazacyclotridecan-12yl)amino)-2-oxoethyl)thio)propanoic Acid (4). To a solution of $\mathrm{NaOMe}$ in methanol (15 mg, $0.28 \mathrm{mmol}$ ) was added equimolar NAC ( $30 \mathrm{mg}, 0.19 \mathrm{mmol})$ and compound 3 $(100 \mathrm{mg}, 0.19 \mathrm{mmol})$ in anhydrous $\mathrm{MeOH}(3 \mathrm{~mL})$ at room temperature under inert conditions. After completion of reaction (checked through TLC), the reaction was quenched with a small amount of water, and the solvent was evaporated using a rotary evaporator to give a sticky yellow compound. The crude compound was then subjected to column chromatography purification using neutral alumina and $20 \%$ methanol in chloroform as a mobile phase to give 4 as a pale yellow-colored compound. (92.41 mg, $0.14 \mathrm{mmol}, 74.8 \%$ ): ${ }^{1} \mathrm{H}$ $\operatorname{NMR}\left(400 \mathrm{MHz}, 25{ }^{\circ} \mathrm{C}, \mathrm{CDCl}_{3}\right): 1.4\left(\mathrm{~s}, 18 \mathrm{H}, \mathrm{CH}_{3}\right), 2.0(\mathrm{~s}$, $\left.3 \mathrm{H}, \mathrm{CH}_{2}\right), 2.8\left(\mathrm{~m}, 8 \mathrm{H}, \mathrm{CH}_{2}\right), 3.1\left(\mathrm{~m}, 4 \mathrm{H}, \mathrm{CH}_{2}\right), 3.4-3.6(\mathrm{~m}$, $\left.8 \mathrm{H}, \mathrm{CH}_{2}\right), 4.5(\mathrm{~s}, 1 \mathrm{H}, \mathrm{CH}), 5.1(\mathrm{~s}, 1 \mathrm{H}, \mathrm{CH}), 7.7(\mathrm{br}, 1 \mathrm{H}$, $\mathrm{NH}), 8.28 .2$ (br, $1 \mathrm{H}, \mathrm{NH}), 8.3$ (br, $1 \mathrm{H}, \mathrm{NH}) .{ }^{13} \mathrm{C}$ NMR (100 $\left.\mathrm{MHz}, 25{ }^{\circ} \mathrm{C}, \mathrm{CDCl}_{3}\right): \delta$ (ppm) 23.0, 28.2, 29.6, 37.3, 53.2, 57.9, $81.6\left(4{ }^{\circ} \mathrm{C}\right), 166.8,170.8,176.3$; ESI-MS ${ }^{+}: \mathrm{m} / z$ calcd for $\mathrm{C}_{28} \mathrm{H}_{48} \mathrm{~N}_{6} \mathrm{O}_{10} \mathrm{~S}[\mathrm{M}+\mathrm{H}]^{+}, 661.32$; found $[\mathrm{M}+\mathrm{H}]^{+}, 661.5$. HRMS (positive mode): $\mathrm{m} / z$ calcd for $\mathrm{C}_{28} \mathrm{H}_{48} \mathrm{~N}_{6} \mathrm{O}_{10} \mathrm{~S}[\mathrm{M}+$ $\mathrm{H}]^{+}, 661.3138$; found $[\mathrm{M}+\mathrm{H}]^{+}, 661.3212$.

Synthesis of 2,2'-(12-(2-((2)-Acetamido-2carboxyethyl)thio)acetamido)-11,13-dioxo-1,4,7,10-tetraazacyclotridecane-4,7-diyl)diacetic Acid (5). To a solution of $20 \%$ TFA in DCM $(5 \mathrm{~mL})$ was added compound 4 (100 mg, $0.15 \mathrm{mmol}$ ) under ice-cold conditions. The reaction was left overnight to stir at room temperature. The resulting solution was applied to a rotary evaporator for complete removal of TFA. This gave compound $\mathbf{5}$ as a yellow solid. (64.23 mg, $0.12 \mathrm{mmol}, 78.16 \%):{ }^{1} \mathrm{H}$ NMR (400 MHz, $\left.25{ }^{\circ} \mathrm{C}, \mathrm{D}_{2} \mathrm{O}\right): 1.9\left(\mathrm{~s}, 3 \mathrm{H}, \mathrm{CH}_{3}\right), 2.8\left(\mathrm{~m}, 1 \mathrm{H}, \mathrm{CH}_{2}\right), 2.9-3.1$ $\left(\mathrm{m}, 9 \mathrm{H}, \mathrm{CH}_{2}\right), 3.3\left(\mathrm{~m}, 4 \mathrm{H}, \mathrm{CH}_{2}\right), 3.6\left(\mathrm{~m}, 6 \mathrm{H}, \mathrm{CH}_{2}\right), 4.3(\mathrm{~s}$, $1 \mathrm{H}, \mathrm{CH}), 4.8(\mathrm{~s}, 1 \mathrm{H}, \mathrm{CH}) .{ }^{13} \mathrm{C}$ NMR $\left(100 \mathrm{MHz}, 25{ }^{\circ} \mathrm{C}\right.$, $\left.\mathrm{D}_{2} \mathrm{O}\right): \delta(\mathrm{ppm}) 21.6,33.3,34.3,51.8,53.0,53.7,58.7,162.3$, 167.4, 172.3, 174.2; ESI-MS ${ }^{+}: m / z$ calcd for $\mathrm{C}_{20} \mathrm{H}_{32} \mathrm{~N}_{6} \mathrm{O}_{10} \mathrm{~S}[\mathrm{M}$ $-\mathrm{H}]^{-}$, 547.18; found $[\mathrm{M}-\mathrm{H}]^{-}$, 547.3. HRMS (positive): $\mathrm{m} /$ $z$ calcd for $\mathrm{C}_{28} \mathrm{H}_{48} \mathrm{~N}_{6} \mathrm{O}_{10} \mathrm{~S}[\mathrm{M}+\mathrm{H}]^{+}, 549.1934$; found $[\mathrm{M}+$ $\mathrm{H}]^{+}, 549.1942$.

Radiolabeling of the Compound. Radiolabeling was performed using the previously published method. ${ }^{30}{ }^{68} \mathrm{Ga}$ $\left(T_{1 / 2}\right.$ value of $68 \mathrm{~min}$ and positron emission of $89 \%$ ) was fractionated from a ${ }^{68} \mathrm{Ge}$ to ${ }^{68} \mathrm{Ga}$ generator. In the generator, ${ }^{68} \mathrm{Ge}$ (half-life $=270$ days) is adsorbed on the titanium dioxidebased inorganic matrix. A total of $5 \mathrm{~mL}$ of $0.1 \mathrm{~N} \mathrm{HCl}$ was injected into the generator to elute ${ }^{68} \mathrm{Ga}$ (III) from the matrix column. The middle fraction was used for radiolabeling to minimize ${ }^{68} \mathrm{Ge}$ breakthrough. $\mathrm{HCl}(12 \mathrm{~N}, 1.25 \mathrm{~mL})$ was added to the eluate to obtain a $5 \mathrm{~N}$ solution of $\left[\mathrm{GaCl}_{4}\right]^{-}$. Dowex-1 of a 200-400 mesh size $(50 \mathrm{mg})$ anion exchange resin was set for trapping $\mathrm{Ga}$ in the gallium chloride $\left[\mathrm{GaCl}_{4}\right]^{-}$form. Thereafter, ${ }^{68} \mathrm{Ga}^{3+}$ elution was accomplished with water. This carrier-free solution was used for hot labeling. $\mathrm{CH}_{3} \mathrm{COONa}$ was used to make the $\mathrm{pH} \approx 4$. To it, $20 \mu \mathrm{mol}$ of ATRIDAT-NAC was added, and the resulting mixture was heated at $90{ }^{\circ} \mathrm{C}$ for a 
duration of $10 \mathrm{~min}$. It was then cooled to room temperature and subjected to a C-18 cartridge purification (preconditioned with ethanol and water and air-dried). ${ }^{68} \mathrm{Ga}$ (III) was washed away with water, and the radiolabeled compound was retained on the cartridge. The ${ }^{68} \mathrm{Ga}(\mathrm{III})$-labeled ATRIDAT-NAC was eluted with $60 \%$ ethanol. ITLC-SG was done to estimate the radiochemical yield in $15 \%$ ammonium acetate/methanol in the ratio of 1:4 as the mobile phase. The ITLC was scanned and analyzed with the OmniScan EZ-TLC scanner and PeakSimple 3.0, respectively.

Cytotoxicity of NAC-ATRIDAT. Cytotoxicity was assessed in the A549 cells using the MTT assay. Cells growing exponentially at a uniform cell density of 4000-5000 cells/well were plated in a 96-well microtiter plate. Cells were treated with increasing concentrations of the test compound ( $\mathrm{pM}$ to $\mathrm{mM}$ range) at intervals of 24,48 and $72 \mathrm{~h}$. At the end of treatment, negative control and treated cells were incubated with MTT $(0.05 \mathrm{mg} / \mathrm{mL})$ for $2 \mathrm{~h}$ at $37^{\circ} \mathrm{C}$, and the medium was removed. Triplicate wells were lysed, and $150 \mu \mathrm{L}$ of DMSO was added to dissolve the formazan crystals. Optical density of $150 \mu \mathrm{L}$ extracts was measured at $570 \mathrm{~nm}$ (reference filter: $630 \mathrm{~nm}$ ). Surviving fraction for the concentration range was plotted against the concentration for ATRIDAT-NAC.

Human Serum Stability Evaluation. Blood was taken from healthy persons (volunteers) and allowed to clot for $1 \mathrm{~h}$ at $37{ }^{\circ} \mathrm{C}$ in a humidified incubator maintained at $5 \% \mathrm{CO}_{2}$ balanced with 95\% air. After clotting, the blood was centrifuged at $400 \mathrm{~g}$. The serum was filtered through a 0.22 $\mu \mathrm{m}$ syringe filter. To $900 \mu \mathrm{L}$ of human serum, $100 \mu \mathrm{L}$ of the radiolabeled compound was added and placed in a $\mathrm{CO}_{2}$ chamber incubated at $37{ }^{\circ} \mathrm{C}$. ITLC was analyzed for dissociation of the complex in the ratio of $1: 4$ of the $15 \%$ ammonium acetate $/ \mathrm{MeOH}$ solvent system.

$\log P$. In a presaturated solution of $500 \mu \mathrm{L}$ each of 1 octanol and PBS, a solution of $20 \mu \mathrm{L}$ of ${ }^{68}$ Ga-labeledATRIDAT-NAC $(50 \mu \mathrm{M})$ was added. The presaturated solution containing the ${ }^{68} \mathrm{Ga}$-labeled-ATRIDAT-NAC was vortexed and centrifuged at $3000 \mathrm{rpm}$ for $10 \mathrm{~min}$. The two phases were separated, and the radioactivity in a volume of 100 $\mu \mathrm{L}$ from each layer was measured in $\gamma$-counter. The experiments were carried out in triplicate. This method is adopted from the previously published article. ${ }^{33}$

Blood Kinetics. The blood kinetics study was performed in female Wistar rat $(\sim 230 \mathrm{~g})$ to analyze the kinetics of radioconjugate clearance from the blood after circulation. ${ }^{68} \mathrm{Ga}$-ATRIDAT-NAC (1 MBq) was injected in the blood stream through the tail vein of the female Wistar rat. The blood samples $(200 \mu \mathrm{L})$ were collected from the occular vein through capillary at different time intervals (10-240 $\mathrm{min}$ ), and counts were measured on a gamma counter. Calculations were done assuming the $64 \mathrm{~mL} / \mathrm{kg}$ blood volume of the rat. Data are given as percentage injected dose (\% ID) at different time frames.

Cell uptake Studies. For cell uptake studies, $0.3 \times 10^{6}$ cells were seeded in DMEM supplemented medium in 24-well culture plates which were incubated overnight. On the next day, the cells/well were counted. The growth medium was replaced by HBSS prior to the experiment. The cells were incubated with the $0.37 \mathrm{MBq}$ of the radiolabeled compound $(500 \mu \mathrm{L})$ and incubated at $37^{\circ} \mathrm{C}$ for $60 \mathrm{~min}$. To terminate the uptake, the tracer solution was removed, and cells were washed with ice-cold PBS. The cells were lysed with $0.2 \mathrm{~N} \mathrm{NaOH}$ (500 $\mu \mathrm{L}$ ), and the radioactivity associated with the cells was counted using the $\gamma$-counter. The results were presented as percentage dose per $10^{5}$ cells (all values were decay corrected).

Cell Binding Studies. Monolayer cultures of the A549 cell line were grown in normal DMEM, supplemented with $10 \%$ FBS. The monolayers were washed with HBSS and left in HBSS for $2 \mathrm{~h}$ at $37^{\circ} \mathrm{C}$ prior to the conduct of the experiment. Saturation and displacement experiments were carried out at $37{ }^{\circ} \mathrm{C}$. Cells were incubated for $1 \mathrm{~h}$ with $(1 \mathrm{pM}$ to $10 \mu \mathrm{M})$ concentration of ${ }^{68} \mathrm{Ga}$-ATRIDAT-NAC with and without the presence of the unlabeled NAC (100 folds excess) to calculate the total and nonspecific binding, respectively. The monolayers were washed with PBS four times after the incubation time. The radioactivity associated with the cells was determined on a gamma counter. Specific binding was calculated by substracting nonbinding fraction from the total binding.

Time Course and Transport Kinetics of ${ }^{68} \mathrm{Ga}$ ATRIDAT-NAC. The time course of the ${ }^{68} \mathrm{Ga}$-ATRIDATNAC uptake was measured by treating the cells with $10 \mu \mathrm{M}$ of the radiolabeled compound in HEPES-buffered Krebs solution $\left(0.5 \mathrm{~mL} ; 37^{\circ} \mathrm{C}\right)$ for different time interval ranges $(30 \mathrm{~s}$ to 60 $\mathrm{min}$ ). Transport of the radiolabeled compound was stopped by removing the radioconjugate and washing three times with PBS. The total activity in cells was measured as stated above in the cell uptake study. A549 cells were incubated for $10 \mathrm{~min}$ in HEPES-buffered Krebs solution (50 $\left.\mu \mathrm{L} ; 37^{\circ} \mathrm{C}\right)$ with concentrations $(0.005-0.1 \mu \mathrm{M})$ of ${ }^{68} \mathrm{Ga}$-ATRIDAT-NAC for kinetic experiments. The data are plotted using the MichaelisMenten equation.

Selectivity and Sodium Ion Dependency of Transport. The inhibition of ${ }^{68} \mathrm{Ga}$-ATRIDAT-NAC transport by amino acids in competition was studied in two different conditions. In the first, cells were incubated with Krebs solution and $10 \mu \mathrm{M}$ solution of ${ }^{68} \mathrm{Ga}$-ATRIDAT-NAC. In second, inhibition studies were carried with $\mathrm{Na}^{+}$-free Krebs solution by substituting sodium salts $\left(\mathrm{NaCl}, \mathrm{NaHCO}_{3}\right.$, and $\mathrm{NaH}_{2} \mathrm{PO}_{4}$ ) with its choline and potassium analogues (choline chloride, choline bicarbonate, and $\mathrm{KH}_{2} \mathrm{PO}_{4}$ ). A549 cells were treated with ${ }^{68} \mathrm{Ga}$-ATRIDAT-NAC for $1 \mathrm{~h}$ at $37^{\circ} \mathrm{C}$ in standard Krebs buffer. After incubation, cells were rinsed and treated with Krebs buffer (standard and modified) consisting of $1 \mathrm{mM}$ of either L-alanine, L-cysteine, DOPA, L-phenyl alanine, or Lglutamine in the group of 4 sets. After $1 \mathrm{~h}$, cells were washed with PBS thrice, followed by the addition of lysis buffer and counts were taken of all the fractions. ${ }^{68} \mathrm{Ga}$-ATRIDAT-NAC efflux was stated as percent of radioactivity effluxed from the cells.

Incorporation of ${ }^{68} \mathrm{Ga}-\mathrm{ATRIDAT}-\mathrm{NAC}$ into Proteins. The incorporation of ${ }^{68} \mathrm{Ga}$-ATRIDAT-NAC into protein was done in concordance to the previously published protocol with slight modifications. ${ }^{26,28}$ For radioligand incorporation in proteins, the samples were treated with $1 \mathrm{MBq}(500 \mu \mathrm{L})$ of ${ }^{68} \mathrm{Ga}-A T R I D A T-N A C$ at $37{ }^{\circ} \mathrm{C}$ for $30 \mathrm{~min}$. At the completion of treatment, the radioactive media were removed, followed by cell washing with $1 \mathrm{~mL}$ ice-cold PBS thrice. The cells were dislodged using $0.5 \mathrm{~mL}$ EDTA (1\%), and $0.5 \mathrm{~mL}$ of $20 \%$ TCA was added to the cells. The samples were kept for $10 \mathrm{~min}$ on ice prior to centrifugation at $10000 \mathrm{rpm}$ for $5 \mathrm{~min}$. The pellet obtained was washed thrice with ice cold PBS. The radioactivity associated with the pellet and the supernatant was quantified by a gamma counter. ${ }^{68}$ Ga-ATRIDAT-NAC integration in the proteins was calculated as the percentage of radioactivity in the precipitated fraction after the TCA addition. 
Biodistribution Studies in Tumor Xenograft Mice Models. Biodistribution studies were done on athymic mice after 10 days of tumor inoculation. The biodistribution of the radiolabeled compound was assessed in A549 tumor xenograft mice after intravenous injection of $100 \mu \mathrm{L}$ of saline holding 1 $\mathrm{MBq}$ of ${ }^{68} \mathrm{Ga}$-ATRIDAT-NAC. After 30, 60, 120, and $240 \mathrm{~min}$ injection of the ${ }^{68} \mathrm{Ga}$-ATRIDAT-NAC, mice $(n=3)$ for each time interval were sacrificed by cervical dislocation following $\mathrm{CO}_{2}$ administration. Organs were harvested and washed with saline and dried on blotting sheets. Organs were then weighed, and the radioactivity in the whole organ was measured by a gamma counter. Percent injected dose per gram of tissues was calculated and plotted.

PET Imaging Studies in Tumor Xenograft Mice Models. The PET imaging study was performed on anesthetized animals by breathing of $2 \%$ isoflurane dissolved in oxygen $(2 \mathrm{~L} / \mathrm{min})$. Each mouse was given ${ }^{68} \mathrm{Ga}$-ATRIDATNAC $(30 \mathrm{MBq})$ intravenously in $100 \mu \mathrm{L}$ of saline intravenously. CT scan was taken of the respective animals for the anatomical frame prior to PET acquisitions at 1,2 , and $4 \mathrm{~h}$ after radioactivity injection. Reconstruction of PET scans was done using 20-50 iterations of the maximum likelihood expectation maximization algorithm. Coregistration of PET and CT was done on AMIRA, and semiquantitative analysis was done using AMIDE. Data are stated as activity in $\mathrm{kBq}$ per $\mathrm{mm}^{3}$ of the tissue.

\section{ASSOCIATED CONTENT}

\section{S Supporting Information}

The Supporting Information is available free of charge on the ACS Publications website at DOI: 10.1021/acsomega.8b00059.

[pp. 1S-13S] NMR and mass spectra of compounds, ITLC, analytical HPLC, blood clearance, and serum stability graph (PDF)

\section{AUTHOR INFORMATION}

\section{Corresponding Authors}

*E-mail: puja.hazari@gmail.com. Phone: +91-01123905244 (P.P.H.).

*E-mail: akmishra63@gmail.com. Phone: +91-01123905117. Fax: +91-01123919509 (A.K.M.).

\section{ORCID}

Anil Kumar Mishra: 0000-0003-2523-9045

\section{Notes}

The authors declare no competing financial interest.

\section{ACKNOWLEDGMENTS}

The present work was supported by Defence Research and Development Organization, Ministry of Defence and University Grants Commission, Delhi. The authors also thank the Director, INMAS and Delhi University for providing necessary facilities.

\section{ABBREVIATIONS}

NAC, N-acetyl L-cysteine; MTT, 3-(4,5-dimethylthiazol-2-yl)2,5-diphenyltetrazonium bromide; PET, positron emission tomography; ROI, region of interest; MLEM, maximum likelihood expectation maximization

\section{REFERENCES}

(1) Johnstone, R. M.; Sholefield, P. G. Amino Acid Transport in Tumor Cells. Advances in Cancer Research; Academic Press, 1965; Vol. 9, pp 143-226.

(2) Jager, P. L.; Vaalburg, W.; Pruim, J.; de Vries, E. G.; Langen, K. J.; Piers, D. A. Radiolabeled amino acids: basic aspects and clinical applications in oncology. J. Nucl. Med. 2001, 42, 432-445.

(3) Low, P. S.; Henne, W. A.; Doorneweerd, D. D. Discovery and Development of Folic-Acid-Based Receptor Targeting for Imaging and Therapy of Cancer and Inflammatory Diseases. Acc. Chem. Res. 2008, 41, 120-129.

(4) Guidotti, G. G.; Borghetti, A. F.; Gazzola, G. C. The regulation of amino acid transport in animal cells. Biochim. Biophys. Acta, Rev. Biomembr. 1978, 515, 329-366.

(5) Haase, C.; Bergmann, R.; Fuechtner, F.; Hoepping, A.; Pietzsch, J. L-Type Amino Acid Transporters LAT1 and LAT4 in Cancer: Uptake of 3-O-Methyl-6- 18F-Fluoro-L-Dopa in Human Adenocarcinoma and Squamous Cell Carcinoma In Vitro and In Vivo. J. Nucl. Med. 2007, 48, 2063-2071.

(6) Hazari, P. P.; Shukla, G.; Goel, V.; Chuttani, K.; Kumar, N.; Sharma, R.; Mishra, A. K. Synthesis of Specific SPECT-Radiopharmaceutical for Tumor Imaging Based on Methionine:99mTcDTPA-bis(methionine). Bioconjugate Chem. 2010, 21, 229-239.

(7) Fuchs, B. C.; Bode, B. P. Amino acid transporters ASCT2 and LAT1 in cancer: Partners in crime? Semin. Cancer Biol. 2005, 15, 254-266.

(8) del Amo, E. M.; Urtti, A.; Yliperttula, M. Pharmacokinetic role of L-type amino acid transporters LAT1 and LAT2. Eur. J. Pharm. Sci. 2008, 35, 161-174.

(9) Cheng, Q.; Beltran, V. D.; Chan, S. M. H.; Brown, J. R.; Bevington, A.; Herbert, T. P. System-L amino acid transporters play a key role in pancreatic $\beta$-cell signalling and function. J. Mol. Endocrinol. 2016, 56, 175-187.

(10) Coenen, H. H.; Kling, P.; Stöcklin, G. Cerebral metabolism of $\mathrm{L}-[2-18 \mathrm{~F}]$ fluorotyrosine, a new PET tracer of protein synthesis. J. Nucl. Med. 1989, 30, 1367-1372.

(11) Langen, K.-J.; Jarosch, M.; Mühlensiepen, H.; Hamacher, K.; Bröer, S.; Jansen, P.; Zilles, K.; Coenen, H. H. Comparison of fluorotyrosines and methionine uptake in F98 rat gliomas. Nucl. Med. Biol. 2003, 30, 501-508.

(12) Wienhard, K.; Herholz, K.; Coenen, H. H.; Rudolf, J.; Kling, P.; Stöcklin, G.; Heiss, W. D. Increased amino acid transport in to brain tumors mesuared by PET of L-(2-18F)fluorotyrosine. J. Nucl. Med. 1991, 32, 1338-1346.

(13) Kubota, K.; Ishiwata, K.; Kubota, R.; Yamada, S.; Takahashi, J.; Abe, Y.; Fukuda, H.; Ido, T. Feasibility of Fluorine-18-Fluorophenylalanine for Tumor Imaging Compared with Carbon-11-L-Methionine. J. Nucl. Med. 1996, 37, 320-325.

(14) Inoue, T.; Tomiyoshi, K.; Higuichi, T.; Ahmed, K.; Sarwar, M.; Aoyagi, K.; Amano, S.; Alyafei, S.; Zhang, H.; Endo, K. Biodistribution studies on L-3-[fluorine-18]fluoro-R-methyl tyrosine: A potential tumor detecting agent. J. Nucl. Med. 1998, 39, 663-667.

(15) Inoue, T.; Shibasaki, T.; Oriuchi, N.; Aoyagi, K.; Tomiyoshi, K.; Amano, S.; Mikuni, M.; Ida, I.; Aoki, J.; Endo, K. 18F R-Methyl tyrosine PET studies in patients with brain tumors. J. Nucl. Med. 1999, 40, 399-405.

(16) Wester, H. J.; Herz, M.; Weber, W.; Heiss, P.; SenekowitschSchmidtke, R.; Schwaiger, M.; Stöcklin, G. Synthesis and radiopharmacology of O- $(2-[18 \mathrm{~F}]$ Fluoroethyl $)$-L-tyrosine for tumor imaging. J. Nucl. Med. 1999, 40, 205-212.

(17) Pauleit, D.; Stoffels, G.; Bachofner, A.; Floeth, F. W.; Sabel, M.; Herzog, H.; Tellmann, L.; Jansen, P.; Reifenberger, G.; Hamacher, K.; Coenen, H. H.; Langen, K.-J. Comparison of 18F-FET and 18F-FDG PET in brain tumors. Nucl. Med. Biol. 2009, 36, 779-787.

(18) Heiss, P.; Mayer, S.; Herz, M.; Wester, H. J.; Schwaiger, M.; Senekowitsch-Schmidtke, R. Investigation of transport mechanism and uptake kinetics of $\mathrm{O}-(2-[18 \mathrm{~F}]$ Fluoroethyl $)$-L-tyrosine in vitro and In Vivo. J. Nucl. Med. 1999, 40, 1367-1373. 
(19) Weber, W. A.; Wester, H.-J.; Herz, M.; Dzewas, B.; Molls, M.; Stöcklin, G.; Schwaiger, M.; Grosu, A. L.; Feldmann, H.-J. O -(2-[ 18 F]Fluoroethyl)- 1 -tyrosine and 1 -[methyl- $11 \mathrm{C}]$ methionine uptake in brain tumours: initial results of a comparative study. Eur. J. Nucl. Med. 2000, 27, 542-549.

(20) McConathy, J.; Voll, R. J.; Yu, W.; Crowe, R. J.; Goodman, M. $\mathrm{M}$. Improved synthesis of anti-[18F]FACBC: improved preparation of labeling precursor and automated radiosynthesis. Appl. Radiat. Isot. 2003, 58, 657-666.

(21) Shoup, T. M.; Goodman, M. M. Synthesis of [F-18]-1-amino-3fluorocyclobutane-1-carboxylic acid (FACBC): a PET tracer for tumor delineation. Radiopharmacy 1999, 42, 215-225.

(22) Shoup, T. M.; Olson, J.; Hoffman, J. M.; Votaw, J.; Eshima, D.; Eshima, L.; Camp, V. M.; Stabin, M.; Votaw, D.; Goodman, M. M. Synthesis and evaluation of [18F]1-amino-3-fluorocyclobutane-1carboxylicacid to image brain tumors. J. Nucl. Med. 1999, 40, 331338.

(23) Martarello, L.; McConathy, J.; Camp, V. M.; Malveaux, E. J.; Simpson, N. E.; Simpson, C. P.; Olson, J. J.; Bowers, G. D.; Goodman, M. M. Synthesis ofsyn- andanti-1-Amino-3-[18F]fluoromethyl-cyclobutane-1-carboxylic Acid (FMACBC), Potential PET Ligands for Tumor Detection. J. Med. Chem. 2002, 45, 2250-2259.

(24) Stryer, L. Biosynthesis of amino acids and heme. Biochemistry; WH Freeman and Co: New York, 1995; pp 713-738.

(25) McConathy, J.; Martarello, L.; Malveaux, E. J.; Camp, V. M.; Simpson, N. E.; Simpson, C. P.; Bowers, G. D.; Olson, J. J.; et al. Radiolabeled Amino Acids for Tumor Imaging with PET: Radiosynthesis and Biological Evaluation of 2-Amino-3-[18F]fluoro-2-methylpropanoic Acid and 3-[18F]Fluoro-2-methyl-2-(methylamino)propanoic Acid. J. Med. Chem. 2002, 45, 2240-2249.

(26) Huang, T.; Tang, G.; Wang, H.; Nie, D.; Tang, X.; Liang, X.; Hu, K.; Yi, C.; Yao, B.; Tang, C. Synthesis and preliminary biological evaluation of S-11C-methyl-d-cysteine as a new amino acid PET tracer for cancer imaging. Amino Acids 2015, 47, 719-727.

(27) Deng, H.; Tang, X.; Wang, H.; Tang, G.; Wen, F.; Shi, X.; Yi, C.; Wu, K.; Meng, Q. S-11C-Methyl-L-Cysteine: A New Amino Acid PET Tracer for Cancer Imaging. J. Nucl. Med. 2011, 52, 287-293.

(28) Urakami, T.; Sakai, K.; Asai, T.; Fukumoto, D.; Tsukada, H.; Oku, N. Evaluation of O-[18F]fluoromethyl-D-tyrosine as a radiotracer for tumor imaging with positron emission tomography. Nucl. Med. Biol. 2009, 36, 295-303.

(29) Bourdier, T., Shepherd, R., Berghofer, P., Jackson, T., Fookes, C. J. R., Denoyer, D., Dorow, D. S., Greguric, I., Gregoire, M.-C.; Hicks, R. J. 2011 Radiosynthesis and Biological Evaluation of l- and dS-(3-[18F]Fluoropropyl)homocysteine for Tumor Imaging Using Positron Emission Tomography. J. Med. Chem. 201154, 1860-1870

(30) Prakash, S.; Hazari, P. P.; Meena, V. K.; Jaswal, A.; Khurana, H.; Kukreti, S.; Mishra, A. K. Biotinidase Resistant 68GalliumRadioligand Based on Biotin/Avidin Interaction for Pretargeting: Synthesis and Preclinical Evaluation. Bioconjugate Chem. 2016, 27, $2780-2790$.

(31) Kilian, K. 68Ga-DOTA and analogs: Current status and future perspectives. Rep. Practical Oncol. Radiother. 2014, 19, S13-S21.

(32) Velikyan, I. Prospective of ${ }^{68} \mathrm{Ga}$-Radiopharmaceutical Development. Theranostics 2014, 4, 47.

(33) Antunes, P.; Ginj, M.; Walter, M. A.; Chen, J.; Reubi, J.-C.; Maecke, H. R. Influence of Different Spacers on the Biological Profile of a DOTA-Somatostatin Analogue. Bioconjugate Chem. 2007, 18, 84-92. 